\title{
Akane Uesugi - Masashi Murakami \\ Do seasonally fluctuating aquatic subsidies influence the distribution pattern of birds between riparian and upland forests?
}

Received: 11 April 2006/ Accepted: 23 June 2006 / Published online: 27 September 2006

(C) The Ecological Society of Japan 2006

\begin{abstract}
Seasonal fluctuation of allochthonous subsidies influences food web structure and dynamics in recipient communities. This study investigated whether aquatic subsidies influence the dynamics of insectivorous birds in entire catchment. We estimated the prey biomass and bird density in riparian and upland habitats in three catchments in temperate deciduous forests in Hokkaido, Japan. Aquatic prey was found only in riparian forests and the biomass peaked in early spring, while terrestrial prey was equally distributed between habitats and increased in biomass in late spring. Bird density was higher in riparian than in upland forests before bud break, when the biomass of aquatic insects peaked, but was similar in both forests during the rest of the seasons. These results suggest that aquatic prey subsidies are used not only by birds inhabiting riparian forests, but also by birds associated with upland forests. Aquatic prey subsidies may be particularly important in the spring as a critical food resource for survival and the breeding activities of birds, thereby, influencing the population dynamics of bird communities.
\end{abstract}

Keywords Allochthonous input · Insectivorous songbirds · Prey switching - Terrestrial productivity · Catchment

\section{Introduction}

The movement of resource subsidies from one habitat to another can strongly influence food web structures and dynamics in adjacent communities (Polis and

\footnotetext{
A. Uesugi $\cdot$ M. Murakami

Tomakomai Research Station, Hokkaido University Forests, Takaoka, Tomakomai, Hokkaido 053-0035, Japan

Present address: A. Uesugi ( $\square)$

Department of Ecology and Evolutionary Biology,

The University of Michigan, Natural Science Building (Kraus), 830 North University, Ann Arbor, MI 48109-1048, USA

E-mail: uakane@umich.edu
}

Hurd 1995; Huxel et al. 2002; Sabo and Power 2002a, 2002b; Baxter et al. 2005). While some studies assume that these allochthonous subsidies are constant over time (Polis and Hurd 1996), seasonal variability in quality and quantity of subsidy input is frequently observed (Nakano and Murakami 2001). Theoretical models show that seasonally fluctuating subsidies stabilize food web dynamics by raising the minimum carrying capacity of recipient habitats during the period of low in-situ productivity if consumers switch their prey preferences to correspond with prey availability (Post et al. 2000; Takimoto et al. 2002). Such subsidy dynamics have been observed (Polis et al. 1997; Nakano and Murakami 2001), but these investigations were limited in their spatial scope to habitats near boundaries. Because subsidies create a mosaic of resource patches across the landscape (Jackson and Fisher 1986), their effects are expected to be carried farther away from boundaries by highly mobile consumers (Rose and Polis 1998; Power et al. 2004).

The emergence of adult aquatic insects from streams may create temporal and spatial heterogeneity in prey availability for insectivorous predators. For instance, in temperate deciduous forests, insectivorous birds in riparian zones forage extensively for aquatic insects in early spring, when terrestrial resources are limited (Nakano and Murakami 2001). However, as terrestrial productivity exceeds the aquatic system during the summer, many birds switch their foraging to terrestrial invertebrates. Distributions of aquatic insects are generally restricted to riparian forests (Gray 1993; Nakano and Murakami 2001), thereby, creating spatial heterogeneity for resources across the catchment. However, it is not known whether such temporal and spatial resource heterogeneity influences community dynamics of birds across the entire catchment.

If aquatic resources are essential for birds in times of low terrestrial productivity, birds with upland territories are expected to aggregate in riparian forests during the early spring. During the summer, the bird distribution between these habitats should become more similar, as 
terrestrial productivity increases. Furthermore, species may respond differently to aquatic resources because of constraints on foraging behaviors (Murakami and Nakano 2001). Generalist species that are capable of switching their prey items between aquatic and terrestrial invertebrates are expected to shift their foraging habitats more than either aquatic or terrestrial prey specialists.

In this study, we measured the seasonal changes in prey abundance and bird density at riparian and upland forest plots. Bird density was higher in riparian than upland plots when aquatic prey was abundant, but was evenly distributed as terrestrial prey biomass increased. In addition, species differed in the degree of aquatic prey use and habitat shift: prey generalist species shifted their foraging habitats more than specialist species.

\section{Materials and methods}

\section{Study sites}

The study was conducted in temperate deciduous forests in the Tomakomai Experimental Forest (TOEF) and the adjacent National Forest $\left(42^{\circ} 41^{\prime} \mathrm{N}, 141^{\circ} 31^{\prime} \mathrm{E}-141^{\circ} 36^{\prime} \mathrm{E}\right)$ in Hokkaido, the northern island of Japan (Fig. 1). The study area encompasses the catchments of Horonai $\left(24 \mathrm{~km}^{2}\right.$ in drainage area, $12.7 \mathrm{~km}$ in total length, $2-5 \mathrm{~m}$ in stream width), Kumanosawa $\left(6.8 \mathrm{~km}^{2}, 2.5 \mathrm{~km}, 1-\right.$ $2 \mathrm{~m}$ ), and Tomakomai $\left(52 \mathrm{~km}^{2}, 24.6 \mathrm{~km}, 2-7 \mathrm{~m}\right)$, all of which are spring-fed and rarely disturbed by floods. The forests are fairly homogeneous across the catchments, and are mainly composed of second-growth deciduous trees, dominated by oak (Quercus crispula), maple (Acer palmatum and A. mono), and cherry (Prunus sargentii).

Insect sampling and bird censuses were conducted in 24 study plots $(100 \times 100 \mathrm{~m})$ established in riparian and upland forests within the three catchments (Fig. 1). We established four riparian plots randomly along the headwater of each stream, and four upland plots approximately $500 \mathrm{~m}$ away parallel to each stream. All study plots were separated by at least $200 \mathrm{~m}$. Vegetation surveys of tree and shrub species were conducted with a $30 \times 2 \mathrm{~m}$ transect per plot. There were no significant differences in the total basal area, species richness, or the Shannon's species diversity index of trees/shrubs between riparian and upland habitats and among the three catchments (two-way ANOVA with habitat and stream as factors, $P>0.07$ for all comparisons).

\section{Study periods}

Insect sampling and bird censuses were performed ten times between May 2001 and July 2002: mid-spring (MSP: 5-20 May), late spring (LSP: 21 May-11 June), early summer (ESU: 11 June-2 July), late summer (LSU: 16 July-6 August), and fall (FL: 25 October-8 November) in 2001; winter (WT: 30 January-21 February), early spring (ESP: 18-28 April), mid-spring (5-16 May), late spring (26 May-12 June), and early summer (18 June-3 July) in 2002. The sampling periods were chosen to match the major phenological changes in canopy trees because the tree phenology strongly influences the abundance of terrestrial invertebrates (Nakano and Murakami 2001). The canopy tree broke buds during late spring, but occurred a few days earlier in upland than in riparian plots. The canopy closed completely by the end of early summer and mature leaves persisted throughout late summer until defoliation in October. Fall sampling was conducted after defoliation, but before snowfall. Snow persisted during winter sampling and melted before early-spring sampling.

\section{Estimation of prey biomass}

Invertebrate biomass was surveyed once at each study plot during each sampling period. We collected aquatic and terrestrial flying insects using a half-sized Malaise trap $[1 \mathrm{~m}$ high $\times 1 \mathrm{~m}$ long $\times 0.6 \mathrm{~m}$ wide, made of $0.5-\mathrm{mm}$ mesh (Townes 1972)] per plot, deployed for 7 days. The traps were placed directly on the ground next to stream
Fig. 1 Map of study plots encompassing three catchments in Tomakomai Experimental Forest (TOEF: shaded area) and the adjacent National Forest. The lines indicate the three streams, Tomakomai, Horonai, and Kumanosawa. The closed and open circles show the location of riparian and upland plots, respectively

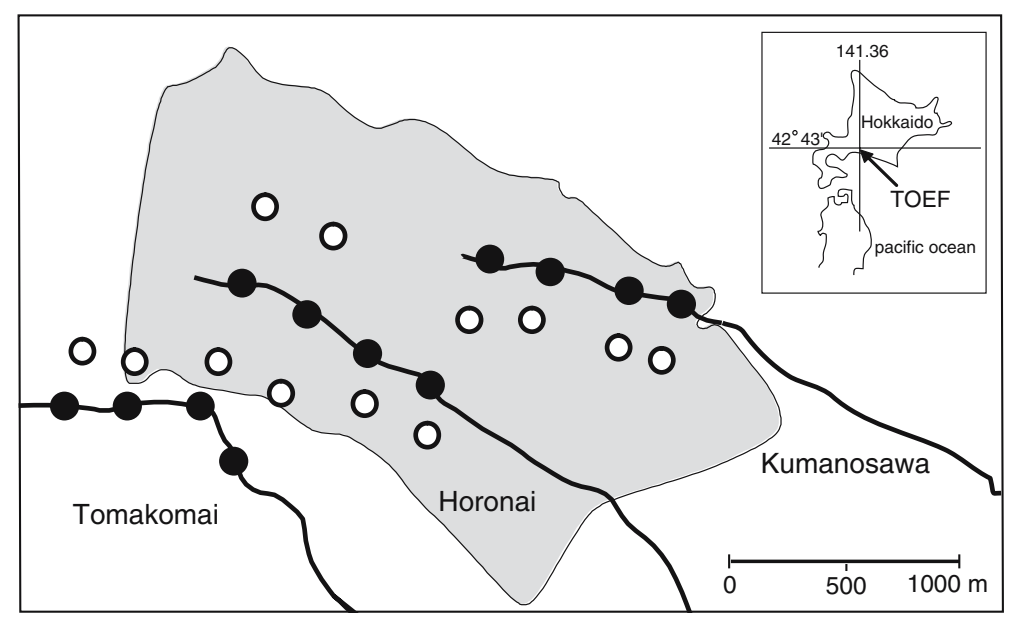


edges in riparian plots and in the middle of each upland plot. Terrestrial arthropods on tree foliage were collected from three oak trees per plot by tapping branches $(>1.5 \mathrm{~m}$ high) with a wooden stick and collected arthropods that dropped onto a sheet $(1 \times 1 \mathrm{~m}$ in area) spread below (Nakano and Murakami 2001). Leaves were carefully checked for remaining invertebrates. During the winter, prey abundance was surveyed at only eight plots in the Horonai Stream catchment (four in each habitat type), due to difficulties in accessing the other catchments.

All insects collected were preserved in $70 \%$ ethanol, identified to order (to family for Diptera and Coleoptera), and sorted into aquatic and terrestrial groups (see Nakano and Murakami 2001 for details). The wet weight of each order or family was measured to the nearest $0.01 \mathrm{mg}$ after blotting for $10 \mathrm{~s}$. Their values were converted to dry weight via taxon-specific wet/dry regressions obtained from previous research (Kawaguchi and Nakano 2001). The biomass is expressed as dry mass (mg) per trap per day for Malaise samples and dry mass (mg) per square meter for foliage samples.

\section{Bird observation}

Bird surveys were conducted by a single observer (A. Uesugi) between dawn and 1100 hours on days of clear visibility with no strong wind. The observer visited each plot four times in a random order during each sampling period. Each observation period lasted for $25 \mathrm{~min}$, and all birds seen or heard within the plot were recorded. Observation was primarily performed at the mid point of the plot, but birds detected near the edge were approached by the observer to determine whether the individual was inside the study plot or not. We avoided multiple recordings of individuals per observation period by keeping track of the locations in which individuals were initially found. A total of 8,460 observations, including 49 forest bird species, were recorded during the entire study period. Of those observations, 7,147 ( $84 \%$ of total) were of 18 common species ( 9 summer migrants and 9 year-round residents), which we selected as focal species for analyses (see Appendix).

The foraging behavior of birds in riparian plots was observed to identify prey items in mid-spring, early summer, and fall of 2001 and in winter 2002. This observation was performed between 0700 and 1100 hours only in riparian plots, since aquatic prey was absent in upland plots. When a bird was encountered, we followed it for $1 \mathrm{~min}$ or until we lost sight of it and recorded its prey items. Since the identification of prey items was often difficult, especially for swarming aquatic insects, we approached the foraging location to check for remaining prey. This often allowed us to estimate prey identity (see Nakano and Murakami 2001). Prey types were classified as adult aquatic invertebrates, terrestrial invertebrates, or plant materials, such as seeds and pollen. We identified prey categories for 1,445 observations $(61.5 \%)$ from a total of 2,348 foraging observations made.

\section{Data analysis}

We analyzed the biomass of arthropods separately for adult aquatic insects, terrestrial flying insects collected in Malaise traps, and for arthropods collected from foliage. Bird density was also analyzed separately for summer migrants and year-round residents. The bird density was estimated by averaging the number of birds observed during the four visits for each season, and expressing density as birds per hour per hectare. The biomass of arthropods and the density of birds were compared between habitats (riparian and upland) and the catchments of three streams (Horonai, Kumanosawa, and Tomakomai), with repeated measures for seasons (sampling periods), using two-way repeated-measures ANOVA with mixed procedure. Differences between habitats for each season were further tested by unpaired t-tests corrected with Bonferroni adjustment. Both invertebrate and bird data were log-transformed for the analysis. Analyses were performed using SAS software, Version 8 (SAS Institute, Inc., Cary, USA).

For each bird species, aquatic prey use $(P)$ in riparian forests was calculated as a proportion of aquatic prey attack to the total amount of foraging observed during each season. A value for aquatic prey preference in each bird species was determined using Jacobs' selectivity index (Jacobs 1974):

$D=\frac{r-p}{r+p-2 r p}$

where $D$ is the preference value for adult aquatic insects, $r$ is the proportion of prey items that were aquatic, and $p$ is the proportion of aquatic insect biomass in the study plots. The value of Jacobs' selectivity index ranges from -1 to +1 , with negative and positive values indicating the avoidance and preference for adult aquatic insects, respectively.

The relationship between the degree of aquatic prey use $(P)$ and habitat shift was examined using a seconddegree polynomial regression model. We defined the degree of habitat shift for a particular species $(H)$ as the change in proportion of individuals in riparian habitats from mid- to late spring:

$H=\operatorname{mean}\left[\frac{R_{\mathrm{m}}}{R_{\mathrm{m}}+U_{\mathrm{m}}}-\frac{R_{\mathrm{l}}}{R_{1}+U_{\mathrm{l}}}\right]$

where $R_{\mathrm{m}}$ and $U_{\mathrm{m}}$ are the bird abundance in riparian and upland plots in mid-spring, respectively and $R_{1}$ and $U_{1}$ in late spring, respectively. Positive values of $H$ indicate that more individuals are found in riparian than in upland plots, and that the difference in abundance between the habitats is greater in mid-spring than in late spring. The values were averaged over 2 years. This analysis was conducted using the statistical package Stat View, Version 5.0.1 (SAS Institute, Inc., Cary, USA). 


\section{Results}

Insect abundance

Adult aquatic insects were found almost exclusively in the riparian forests, and the biomass peaked in early to midspring before bud break (Fig. 2a). There was no effect of catchment $\left(F_{2,18}=0.46, P=0.64\right)$. Significant habitat $\times$ season interaction $\left(F_{9,162}=5.64, P<0.0001\right)$ indicated that between-habitat differences in aquatic insect biomass varied across seasons. Nevertheless, abundance was higher in riparian than upland habitats in all seasons (d.f. $=22, t>3.4, P<0.001$ for all comparisons).

Terrestrial flying insects were found in both riparian and upland habitats with no habitat effect $\left(F_{1,18}=0.99\right.$, $P=0.33$ ). Their biomass was relatively low in early to mid-spring, rapidly increased as trees leafed out in late spring, and dropped to almost zero in fall and winter (Fig. 2b). This general pattern was observed in all three
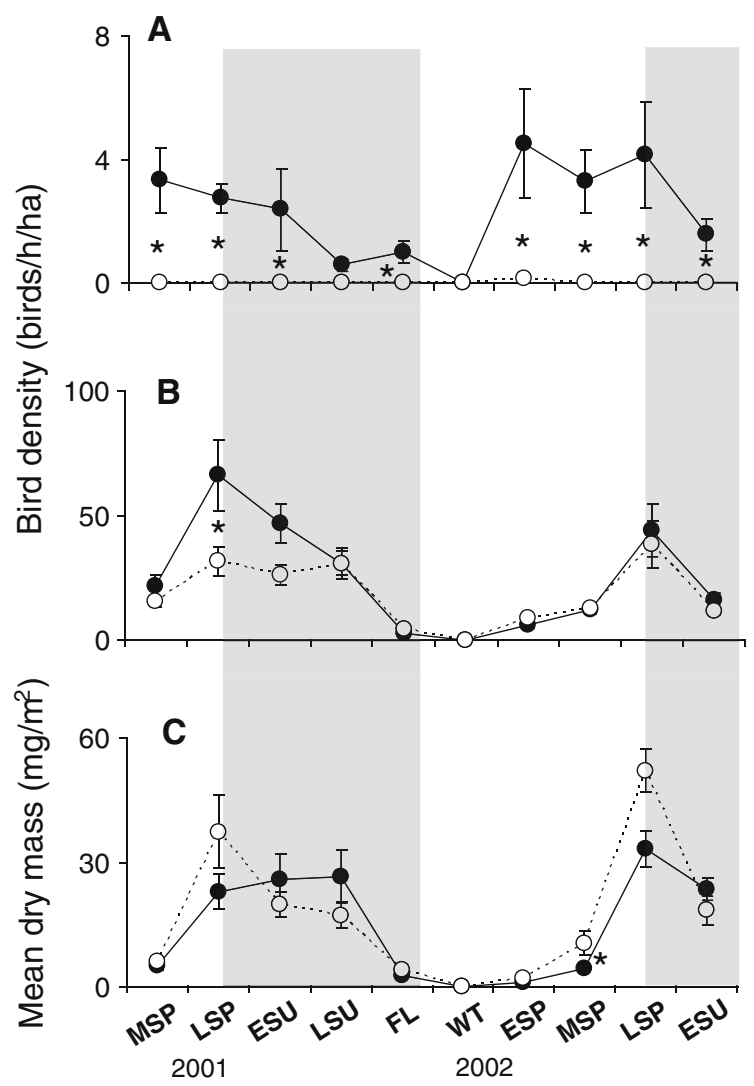

Fig. 2a-c Seasonal changes in the biomass of potential prey arthropods. a Adult aquatic insects. b Terrestrial flying insects. c Arthropods on foliage. Closed circles represent the biomass in riparian three plots and open circles in upland plots. The asterisks indicate significant between-habitat differences (unpaired t-tests with Bonferroni adjustment for ten tests). The sampling periods are indicated as follows: $M S P$ mid spring; $L S P$ late spring; $E S U$ early summer; $L S U$ late summer; $F L$ fall; and $W T$ winter (see Study periods section for specific dates). The shaded areas represent periods of leafing in canopy trees. Data shown include means and standard errors catchments, although the biomass was exceptionally high in Kumanosawa riparian plots in late spring 2001 (effect of catchment: $F_{2,18}=6.65, P=0.006$ ). There were season $\times$ habitat interactions $\left(F_{9,162}=3.01, P=0.002\right)$, but no differences in biomass were observed between riparian and upland habitats in all seasons $(t<2.7$, $P>0.12$ for all comparisons).

Terrestrial insects on foliage were equally abundant in riparian and upland habitats $\left(F_{1,18}=2.73, P=0.11\right)$, and showed a seasonal pattern similar to the terrestrial flying insects (Fig. 2c). An increase in late spring was largely due to the emergence of lepidopteran larvae, which accounted for more than $70 \%$ of the total biomass. There was no effect of catchment $\left(F_{2}, 18=0.34\right.$, $P=0.71)$ and no differences between riparian and upland habitats in each season $(t<2.9, P>0.07$ for all comparisons). These results indicate that terrestrial invertebrates were evenly distributed between riparian and upland forests during each season.

\section{Bird diet and distribution pattern}

Birds observed in riparian habitats preyed upon adult aquatic insects frequently in the spring $(39.4 \%$ of total observation, Table 1), but rarely in the summer (5.6\%). In the spring, seven bird species preferred adult aquatic insects to terrestrial flying insects as prey $(D>0)$. During the fall and winter, non-migratory resident birds preyed on adult aquatic insects for $27.4 \%$ and $9.0 \%$ of the time, respectively (Table 1 ).

Bird densities for both residents and migrants were, in general, higher in riparian than upland habitat plots in early to mid-spring, but were similar during other seasons (Fig. 3a, b). Similar distribution patterns were observed in all three catchments (no catchment effect: $F_{2,18}=2.49$, $P=0.11$ and $F_{2,18}=0.85, P=0.44$ for migrants and residents, respectively), but the seasonal pattern in bird density was different between habitats (season $\times$ habitat interaction: $F_{9,162}=7.62, P<0.0001$ and $F_{9,162}=2.53$, $P=0.01$ for migrants and residents, respectively). Migrants showed higher abundance in riparian than upland habitat in mid-spring during both years $(t>5.7$, $P<0.001)$, and the difference was already prominent in early spring $2002(t=3.3, P=0.02)$. In late spring, the migrant bird density decreased in the riparian habitat, but increased in the upland habitat, eliminating the difference between the two habitats $(t>2.5, P>0.18$, Fig. 3$)$. Residents showed no difference between habitats in any season ( $t<2.7, P>0.15$ after Bonferroni correction).

The above seasonal distribution patterns also varied between bird species. Generalist species that used aquatic prey at an intermediate level showed the highest degree of habitat shifts, while specialist species that foraged on aquatic prey at low or high levels were less likely to shift (Fig. 4). This relationship was significant when the data was fitted to the second-degree polynomial regression model $\left(P=0.03, r^{2}=0.38\right)$, but not when fitted with the linear regression model $\left(P=0.13, r^{2}=0.14\right)$. 
Table 1 Percentage of aquatic prey items in diets of bird species foraging in riparian forest plots in the spring, summer, fall, and winter. Sample sizes ( $n$, the number of observations) are shown in parentheses
- Absence of data

${ }^{\text {a }}$ Positive preferences for aquatic prey by Jacob's selectivity index (D)

\begin{tabular}{llllll}
\hline & Species & Spring & Summer & Fall & Winter \\
\hline Summer & migrants & & & & \\
BF & Brown flycatcher & $84.9^{\mathrm{a}}(53)$ & $25.9(27)$ & - & - \\
PWW & Pale-legged willow warbler & $80^{\mathrm{a}}(40)$ & $29.2(24)$ & - & - \\
CW & Eastern crowned willow warbler & $76.9^{\mathrm{a}}(26)$ & $5.56(36)$ & - & - \\
BWF & Blue and white flycatcher & $70.4^{\mathrm{a}}(27)$ & $26.3(19)$ & - & - \\
GTH & Japanese grey thrush & $62.5^{\mathrm{a}}(16)$ & $0(16)$ & - & - \\
NF & Narcissus flycatcher & $52.4^{\mathrm{a}}(42)$ & $8.16(49)$ & - & - \\
TP & Olive-backed tree pipit & $42.2(45)$ & $0(16)$ & - & - \\
BFB & Black-faced bunting & $40(40)$ & $0(51)$ & - & - \\
BW & Short-tailed bush warbler & $38.5(26)$ & $0(16)$ & - & - \\
Residents & & & & & \\
GT & Great tit & $55.6^{\mathrm{a}}(72)$ & $0(49)$ & $29.4(17)$ & $0(2)$ \\
NH & Nuthatch & $46.4(28)$ & $0(33)$ & $8.2(49)$ & $13.2(38)$ \\
TC & Tree creeper & $37.9(29)$ & $0(5)$ & $0(10)$ & $22.2(18)$ \\
PWP & Japanese pigmy woodpecker & $20.9(43)$ & $0(16)$ & $0(12)$ & $0(11)$ \\
MT & Marsh tit & $13.2(53)$ & $0(66)$ & $6.3(64)$ & $5.1(39)$ \\
VT & Varied tit & $7.41(27)$ & $0(2)$ & $0(2)$ & $50.0(2)$ \\
CT & Coal tit & $0(78)$ & $-(0)$ & $-(0)$ & $0(1)$ \\
GWP & Great spotted woodpecker & $0(29)$ & $0(17)$ & $0(6)$ & $0(3)$ \\
LT & Long-tailed tit & $0(24)$ & $0(3)$ & $0(20)$ & $0(8)$ \\
& All species & $39.4(698)$ & $5.6(445)$ & $27.4(180)$ & $9.0(122)$ \\
\hline
\end{tabular}

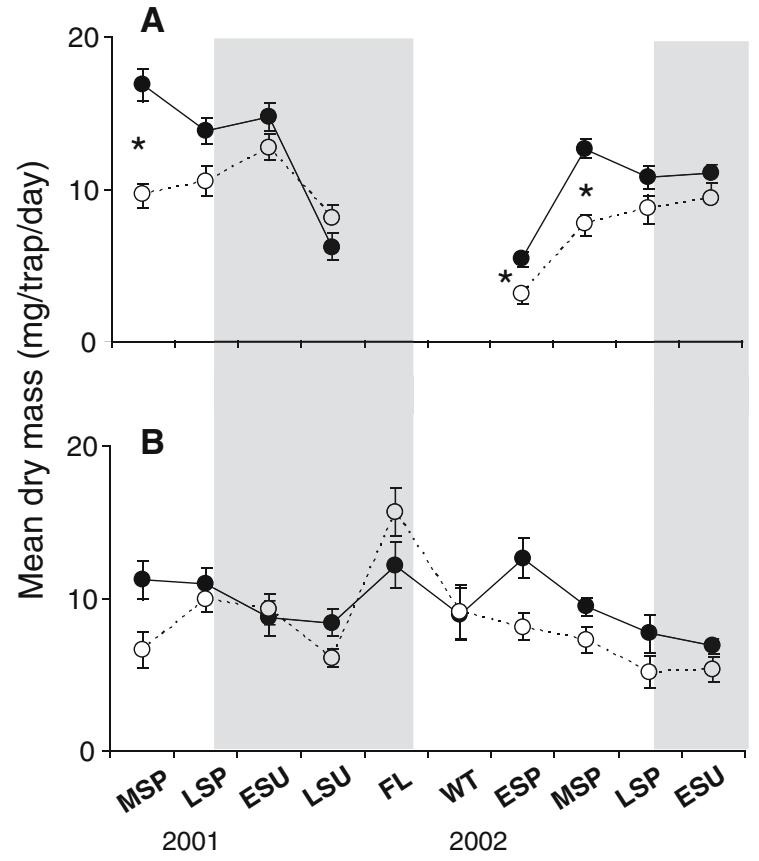

Fig. 3a, b Seasonal changes in bird density (birds/h/ha) for summer migrants (a) and year-round residents (b) in the riparian (closed circles) and upland (open circles) habitat plots from midspring 2001 to early summer 2002. Details are in Fig. 2

\section{Discussion}

The bird distribution patterns were consistent with our hypothesis that birds move between habitats in response to fluctuating resource availability. The presence of aquatic insects was restricted to riparian habitat and became available when terrestrial resources were limited. During the early spring, the total biomass of aquatic insects (Fig. 1a) was lower than terrestrial flying insects

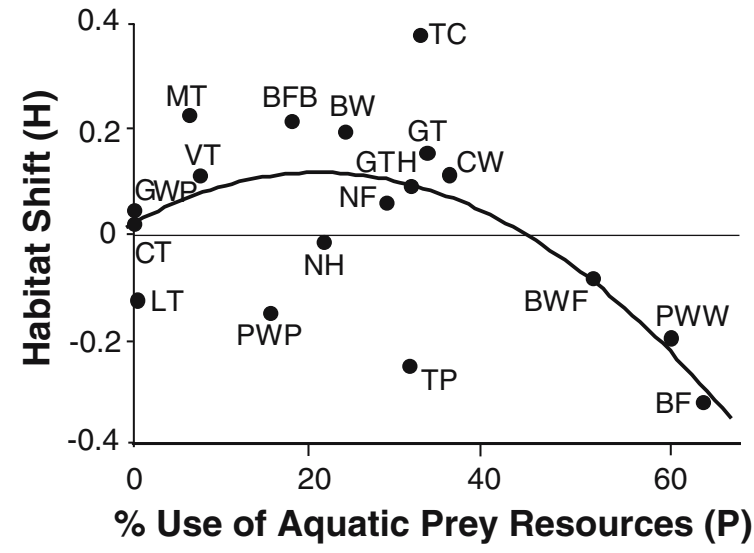

Fig. 4 Regression plots for the degree of habitat shift $(H)$ against the percentage use of aquatic resources $(P)$. Each point indicates a particular species (see Appendix for abbreviation codes). The fitted line reflects a second-degree polynomial regression $(Y=-0.012+$ $0.009 X-0.0002 X^{2} ; P=0.03, r^{2}=0.37$, see Materials and methods section)

(Fig. 1b), but seven species of birds selectively preyed upon the aquatic insects, indicating that the aquatic insects may be more important as prey resources than terrestrial flying insects. This preference for aquatic insects may be due to their slow movements and higher nutritional quality, as suggested elsewhere (Smith et al. 1998; Nakano and Murakami 2001; Iwata et al. 2003). The late-spring emergence of lepidopteran larvae homogenized the resource environment and reduced the relative importance of aquatic subsidies. At this time, birds that had been foraging on adult aquatic insects in riparian forests switched prey items to terrestrial invertebrates. Seasonal variation in foraging strategy has been reported for various species of birds (Smith et al. 1998; Murakami and Nakano 2001), and the ability to 
switch foraging method is thought to maximize energy gain during periods of low resource supply (Keast 1990).

Previous studies have examined the effect of aquatic subsidies on insectivorous birds (Gray 1993; Smith et al. 1998; Gende and Willson 2001; Nakano and Murakami 2001), but these investigations were limited to riparian forests. Our study on bird distribution patterns indicates that the effect of subsidies is carried throughout the catchment. High riparian density in early spring suggests that birds establishing territories in upland habitats may commute to riparian forests, which is consistent with the reports of birds foraging outside nesting territories (Davies 1976; Nagai 2000). In summer, birds dispersed throughout the catchment and were observed foraging with increased proximity to their nests (A. Uesugi, personal observations).

The seasonal distribution pattern was more prominent in migratory birds than non-migrants, suggesting that aquatic insects are an especially important resource to early migrants, as demonstrated by other works (McCarty 1997; Smith et al. 1998). However, not all species responded to the aquatic subsidies in the same manner. Prey generalists that use aquatic prey at an intermediate level exhibit a higher degree of habitat shift than specialists of either aquatic or terrestrial prey (Fig. 4). Generalists' ability to shift foraging habitat suggests that the spatial and temporal variation of aquatic subsidies could maintain high species diversity by allowing generalists, which may be otherwise competitively excluded by specialists, to persist within a catchment.

The seasonal patterns we present are indicative of catchment-wide movements of birds across habitats. However, our methods of inferring bird movements have some limitations. First, while our method allows us to infer the general patterns of seasonal changes over a large spatial scale, it lacks resolution at an individual level because we did not track each individual bird. Individual tracking methods, such as radio telemetry, allow researchers to determine the exact movement of the bird, and have been implemented in behavioral studies in passerines (Goguen and Mathews 2001; Norris and Stutchbury 2002). However, tracking methods are limited by expense, sample size, and the temporal and spatial scales that can be implemented. Our results indicate dynamic bird movements in the spring, but individual bird behaviors can be further examined with radio telemetry to complement this information.

Increased upland bird density during the late spring may not completely reflect the movement of birds from riparian forests. Since the total area of riparian forest $(<100 \mathrm{~m}$ from a stream) in the study catchments is approximately $10 \%$ of upland forest (see Study sites section), the individuals that left the riparian may not account for the total increase in bird abundance in the upland plots. Although most migrants arrived before the mid-spring sampling periods (A. Uesugi, personal observations), the influx of late migrants to upland forest could contribute to this increase. Nevertheless, the bird density in all riparian plots decreased after bud break, indicating that at least some birds foraging near streams moved to upland forests.

Other factors, aside from aquatic subsidies, may also influence the seasonal distribution patterns of birds. Strong territoriality may negatively impact potential habitat shifts for certain species. For example, Narcissus flycatchers display a high degree of prey switching, but do not appear to shift foraging habitat. Since male Narcissus flycatchers defend their established territories constantly by chasing intruders away (A. Uesugi, personal observations), they are probably less likely to forage outside of their territories.

Forest vegetation structure is another factor that may influence bird distribution patterns in catchments (Jackson and Fisher 1986; McGarigal and McComb 1992; Murray and Stauffer 1995; Lock and Naiman 1998). For example, bird abundance is positively correlated with the percentage of deciduous trees in species that require hardwoods for successful breeding (Lock and Naiman 1998). We minimized the effect of vegetation structure by conducting surveys in relatively homogenous forests across the catchment (see Materials and methods section). Our methods, therefore, allowed us to examine the direct effect of aquatic prey on bird distributions.

The input of aquatic prey may be critical for maintaining bird populations within catchments. Because spring food availability is most limited before bud break, over-wintering passerines often suffer severe mortality (Payne and Wilson 1999), and aquatic prey subsidies may facilitate bird survival during this period. Migrants encounter less phenologically advanced vegetation as they migrate north, and aquatic prey subsidies are known to provide them with food resources critical to their recovery from the long trip (Ewert and Hamas 1995). Subsidies may also enhance the breeding success of birds by supporting territorial and courtship activities, as well as influencing the timing of egg-laying (Svensson and Nilsson 1995) and clutch sizes (Nager et al. 1997; Olsson et al. 2001).

The effects of aquatic subsidies may be more widespread in landscape than has been previously appreciated. Aquatic resources can influence the population dynamics of highly mobile consumers that are associated with habitats beyond the boundary areas, such as coyotes (Rose and Polis 1998), bears (Ben-David et al. 1998), bats (de Jong and Ahlen 1991; Power et al. 2004), and rodents (Stapp and Polis 2003). As a consequence, energy and nutrients from aquatic resource subsidies will be distributed throughout catchments by their movements. Our findings suggest that the effects of seasonally fluctuating subsidies could propagate throughout catchments via the movement of insectivorous birds. As a result, these movements of consumers may strongly affect population dynamics and food web structures. 
Acknowledgments We thank M. Toda, K. Fausch, C. Baxter, and $\mathrm{T}$. Iwata for their inspiring comments regarding the study. T. Connallon greatly improved the manuscript. We are also grateful to the many staff and graduate students at Tomakomai Research Station, Hokkaido University, Japan, for their support during the study, especially to T. Ishii for logistic support and H. Asano, K. Ono, and A. Okuda for identifying invertebrates and bird specimens. Financial support was provided by Japanese Ministry of Education, Science, Sport and Culture (grant nos. 09NP1501 and 11440224).

\section{Appendix}

Table 2 Bird species (names and abbreviations) observed during the study period

\begin{tabular}{|c|c|c|c|c|}
\hline Abbreviation & Species & $\begin{array}{l}\text { Total } \\
\text { sightings }\end{array}$ & $\begin{array}{l}\text { Focal } \\
\text { species }\end{array}$ & Migration \\
\hline $\mathrm{FC}$ & Accipiter gularis (Japanese Lesser Sparrowhawk) & 3 & & $\mathrm{~S}$ \\
\hline LT & Aegithalos caudatus (Long-tailed Tit) & 245 & $\mathrm{O}$ & $\mathrm{R}$ \\
\hline TP & Anthus hodgsoni (Olive-backed Tree Pipit) & 132 & $\mathrm{O}$ & $\mathrm{S}$ \\
\hline OG & Carduelis sinica (Oriental Greenfinch) & 43 & & $\mathrm{~S}$ \\
\hline SI & Carduelis spinus (Siskin) & 3 & & $\mathrm{R}$ \\
\hline $\mathrm{TC}$ & Certhia familiaris (Treecreeper) & 349 & $\mathrm{O}$ & $\mathrm{R}$ \\
\hline JBW & Cettia diphone (Japanese Bush Warbler) & 80 & & $\mathrm{~S}$ \\
\hline BW & Cettia squameiceps (Short-tailed Bush Warbler) & 290 & $\mathrm{O}$ & $\mathrm{S}$ \\
\hline $\mathrm{HF}$ & Coccothraustes coccothraustes (Hawfinch) & 22 & & $\mathrm{~S}$ \\
\hline $\mathrm{CC}$ & Corvus macrorhynchos (Jungle Crow) & 15 & & $\mathrm{R}$ \\
\hline $\mathrm{OC}$ & Cuculus saturatus (Oriental Cuckoo) & 9 & & $\mathrm{~S}$ \\
\hline BWF & Cyanoptila cyanomelana (Blue and white Flycatcher) & 122 & $\mathrm{O}$ & $\mathrm{S}$ \\
\hline BWP & Dryocopus martius (Black Woodpecker) & 2 & & $\mathrm{R}$ \\
\hline $\mathrm{MB}$ & Emberiza cioides (Siberian Meadow Bunting) & 2 & & $\mathrm{~S}$ \\
\hline $\mathrm{BFB}$ & Emberiza spdocephala (Black-faced Bunting) & 902 & $\mathrm{O}$ & $\mathrm{S}$ \\
\hline GB & Emberiza variabilis (Japanese Grey Bunting) & 4 & & $\mathrm{~S}$ \\
\hline JG & Eophona personata (Japanese Grosbeak) & 193 & & $\mathrm{~S}$ \\
\hline $\mathrm{JR}$ & Erithacus akahige (Japanese Robin) & 3 & & $\mathrm{~S}$ \\
\hline SBR & Erithacus cyane (Siberian Blue Robin) & 3 & & $\mathrm{~S}$ \\
\hline MF & Erithacus cyanurus (Red-flanked Bluetail) & 8 & & $\mathrm{~S}$ \\
\hline $\mathrm{NF}$ & Ficedula narcissina (Narcissus Flycatcher) & 859 & $\mathrm{O}$ & $\mathrm{S}$ \\
\hline JA & Garrulus glandarius (Jay) & 28 & & $\mathrm{R}$ \\
\hline BB & Hypsipetes amaurotis (Brown-eared Bulbul) & 210 & & $\mathrm{R}$ \\
\hline JPW & Motacilla alba (Pied Wagtail) & 3 & & $\mathrm{~S}$ \\
\hline $\mathrm{BF}$ & Muscicapa dauurica (Brown Flycatcher) & 99 & $\mathrm{O}$ & $\mathrm{S}$ \\
\hline $\mathrm{CT}$ & Parus ater (Coal Tit) & 551 & $\mathrm{O}$ & $\mathrm{R}$ \\
\hline GT & Parus major (Great Tit) & 823 & $\mathrm{O}$ & $\mathrm{R}$ \\
\hline MT & Parus palustris (Marsh Tit) & 871 & $\mathrm{O}$ & $\mathrm{R}$ \\
\hline VT & Parus varius (Varied Tit) & 213 & $\mathrm{O}$ & $\mathrm{R}$ \\
\hline RS & Passer rutilans (Cinnamon Sparrow) & 41 & & $\mathrm{~S}$ \\
\hline $\mathrm{CW}$ & Phylloscopus coronatus (Eastern Crowned Willow Warbler) & 893 & $\mathrm{O}$ & $\mathrm{S}$ \\
\hline PWW & Phylloscopus tenellipes (Pale-legged Willow Warbler) & 174 & $\mathrm{O}$ & $\mathrm{S}$ \\
\hline PWP & Picoides kizuki (Japanese Pigmy Woodpecker) & 410 & $\mathrm{O}$ & $\mathrm{R}$ \\
\hline WWP & Picoides leucotos (White-backed Woodpecker) & 28 & & $\mathrm{R}$ \\
\hline GWP & Picoides major (Great Spotted Woodpecker) & 197 & $\mathrm{O}$ & $\mathrm{R}$ \\
\hline GGW & Picus canus (Grey-headed Green Woodpecker) & 6 & & $\mathrm{R}$ \\
\hline BUF & Pyrrhula pyrrhula (Bullfinch) & 25 & & W \\
\hline $\mathrm{GC}$ & Regulus regulus (Goldcrest) & 29 & & $\mathrm{R}$ \\
\hline NH & Sitta europea (Nuthatch) & 643 & $\mathrm{O}$ & $\mathrm{R}$ \\
\hline ST & Sturnus cineraceus (Grey Starling) & 2 & & $\mathrm{R}$ \\
\hline SS & Sturnus philippensis (Violet-backed Starling) & 1 & & $\mathrm{~S}$ \\
\hline JGP & Treron sieboldii (Japanese Green Pigeon) & 2 & & $\mathrm{~S}$ \\
\hline WR & Troglodytes troglodytes (Wren) & 59 & & $\mathrm{~W}$ \\
\hline GTH & Turdus cardis (Japanese Grey Thrush) & 454 & $\mathrm{O}$ & $\mathrm{S}$ \\
\hline ВТН & Turdus chrysolaus (Red-bellied Thrush) & 19 & & $\mathrm{~S}$ \\
\hline DTH & Turdus naumanni (Dusky Thrush) & 14 & & W \\
\hline WTH & Zoothera dauma (White's Thrush) & 28 & & $\mathrm{~S}$ \\
\hline SGT & Zoothera sibirica (Siberian Ground Thrush) & 1 & & $\mathrm{~S}$ \\
\hline WE & Zosterops japonica (Japanese White-eye) & 9 & & $\mathrm{~S}$ \\
\hline
\end{tabular}

Total sightings and migration behavior are indicated. Focal species used in analyses are indicated as $\mathrm{O}$ $S$ summer migrants, $W$ winter migrants, $R$ residents 


\section{References}

Baxter CV, Fausch KD, Saunders WC (2005) Tangled webs: reciprocal flows of invertebrate prey link streams and riparian zones. Freshw Biol 50(2):201-220

Ben-David M, Hanley TA, Schell DM (1998) Fertilization of terrestrial vegetation by spawning Pacific salmon: the role of flooding and predator activity. Oikos 83(1):47-55

Davies NB (1976) Food, flocking and territorial behaviour of the pied wagtail (Motacilla alba yarrellii Gould) in winter. J Anim Ecol 45(1):235-253

de Jong J, Ahlen I (1991) Factors affecting the distribution pattern of bats in Uppland, central Sweden. Holarct Ecol 14:92-96

Ewert D, Hamas M (1995) Ecology of migratory landbirds during migration in the Midwest. In: Tompson FR (ed) Management of midwestern landscapes for the conservation of neotropical migratory birds. United States Department of Agriculture, St. Paul, Minnesota, General Technical Report NC-187, pp 200 208

Gende SM, Willson MF (2001) Passerine densities in riparian forests of southeast Alaska: potential effects of anadromous spawning salmon. Condor 103(3):624-629

Goguen CB, Mathews NE (2001) Brown-headed cowbird behavior and movements in relation to livestock grazing. Ecol Appl 11(5): $1533-1544$

Gray LJ (1993) Response of insectivorous birds to emerging aquatic insects in riparian habitats of a tallgrass prairie stream. Am Midl Nat 129(2):288-300

Huxel GR, McCann K, Polis GA (2002) Effects of partitioning allochthonous and autochthonous resources on food web stability. Ecol Res 17(4):419-432

Iwata T, Nakano S, Murakami M (2003) Stream meanders increase insectivorous bird abundance in riparian deciduous forests. Ecography 26(3):325-337

Jacobs J (1974) Quantitative measurement of food selection: modification of the forage ratio and Ivlev's electivity index. Oecologia 14:413-417

Jackson JT, Fisher SG (1986) Secondary production, emergence, and export of aquatic insects of a Sonoran Desert stream. Ecology 67(3):629-638

Kawaguchi Y, Nakano S (2001) Contribution of terrestrial invertebrates to the annual resource budget for salmonids in forest and grassland reaches of a headwater stream. Freshw Biol 46(3):303-316

Keast A (1990) The annual cycle and activity on the breeding grounds in a Canadian broad-leafed deciduous forest bird community, relationship to the prey resource base. In: Keast A (ed) Biogeography and ecology of forest bird community. SPB Academic Publishing, The Hague, pp 197-214

Lock PA, Naiman RJ (1998) Effects of stream size on bird community structure in coastal temperate forests of the Pacific Northwest, USA. J Biogeogr 25(4):773-782

McCarty JP (1997) Aquatic community characteristics influence the foraging patterns of Tree Swallows. Condor 99(1):210 213

McGarigal K, McComb WC (1992) Streamside versus upslope breeding bird communities in the Central Oregon Coast Range. J Wildl Manage 56(1):10-23

Murakami M, Nakano S (2001) Species-specific foraging behavior of birds in a riparian forest. Ecol Res 16(5):913-923
Murray NL, Stauffer DF (1995) Nongame bird use of habitat in central Appalachian riparian forests. J Wildl Manage 59(1):7888

Nagai A (2000) Frequent use of foraging sites outside the territory during the nestling period observed in a pair of Great Tit Parus major. STRIX 18:115-119

Nager RG, Ruegger C, Van Noordwijk AJ (1997) Nutrient or energy limitation on egg formation: a feeding experiment in great tits. J Anim Ecol 66(4):495-507

Nakano S, Murakami M (2001) Reciprocal subsidies: dynamic interdependence between terrestrial and aquatic food webs. Proc Natl Acad Sci USA 98(1):166-170

Norris DR, Stutchbury BJM (2002) Sexual differences in gapcrossing ability of a forest songbird in a fragmented landscape revealed through radio tracking. Auk 119(2):528-532

Olsson O, Wiktander U, Malmqvist A, Nilsson SG (2001) Variability of patch type preferences in relation to resource availability and breeding success in a bird. Oecologia 127(3):435-443

Payne RJH, Wilson JD (1999) Resource limitation in seasonal environments. Oikos 87(2):303-314

Polis GA, Hurd SD (1995) Extraordinarily high spider densities on islands: flow of energy from the marine to terrestrial food webs and the absence of predation. Proc Natl Acad Sci USA 92(10):4382-4386

Polis GA, Hurd SD (1996) Linking marine and terrestrial food webs: allochthonous input from the ocean supports high secondary productivity on small islands and coastal land communities. Am Nat 147(3):396-423

Polis GA, Hurd SD, Jackson CT, Pinero FS (1997) El Nino effects on the dynamics and control of an island ecosystem in the Gulf of California. Ecology 78(6):1884-1897

Post DM, Conners ME, Goldberg DS (2000) Prey preference by a top predator and the stability of linked food chains. Ecology 81(1):8-14

Power ME, Rainey WE, Parker MS, Sabo JL, Smyth A, Khandwala S, Finlay JC, McNeely FC, Marsee K, Anderson C (2004) River to watershed subsidies in an old-growth conifer forest. In: Polis GA, Power ME, Huxel G (eds) Food webs and landscapes. Chicago University Press, Chicago, Illinois, pp 217-240

Rose MD, Polis GA (1998) The distribution and abundance of coyotes: the effects of allochthonous food subsidies from the sea. Ecology 79(3):998-1007

Sabo JL, Power ME (2002a) Numerical response of lizards to aquatic insects and short-term consequences for terrestrial prey. Ecology 83(11):3023-3036

Sabo JL, Power ME (2002b) River-watershed exchange: effects of riverine subsidies on riparian lizards and their terrestrial prey. Ecology 83(7):1860-1869

Smith R, Hamas M, Dallman M, Ewert D (1998) Spatial variation in foraging of the Black-throated Green Warbler along the shoreline of northern Lake Huron. Condor 100(3):474-484

Stapp P, Polis GA (2003) Influence of pulsed resources and marine subsidies on insular rodent populations. Oikos 102(1):111-123

Svensson E, Nilsson JA (1995) Food-supply, territory quality, and reproductive timing in the blue tit (Parus caeruleus). Ecology 76(6):1804-1812

Takimoto G, Iwata T, Murakami M (2002) Seasonal subsidy stabilizes food web dynamics: balance in a heterogeneous landscape. Ecol Res 17(4):433-439

Townes H (1972) A light-weight Malaise trap. Entomol News $83: 239-247$ 